\title{
Occurrence of viral diseases in donkeys (Equus asinus) in São Paulo State, Brazil
}

\section{Ocorrência de enfermidades virais em asininos (Equus asinus) no estado de São Paulo, Brasil}

\author{
Maria do Carmo Custódio de Souza Hunold LARA ${ }^{1}$; Eliana Monteforte CassaroVILLALOBOS ${ }^{1}$; \\ Elenice Maria Sequetin CUNHA ${ }^{1}$; José Victor de OLIVEIRA²; Vanessa CASTRO'; \\ Alessandra Figueiredo de Castro NASSAR ${ }^{1}$; Lília Márcia Paulin SILVA ${ }^{1}$; Liria Hiromi OKUDA ${ }^{1}$; \\ Adriana Hellmeister de Campos Nogueira ROMALDINI'; Mariana Sequetin CUNHA'; \\ Eduardo Carvalho MARQUES ${ }^{1}$; Enio MORI ${ }^{4}$ \\ ${ }^{1}$ Instituto Biológico, São Paulo - SP, Brazil \\ ${ }^{2}$ Polo Regional Alta Mogiana, Colina - SP, Brazil \\ ${ }^{3}$ Instituto Adolfo Lutz, São Paulo - SP, Brazil \\ ${ }^{4}$ Instituto Pasteur, São Paulo - SP, Brazil
}

\begin{abstract}
Among the diseases that affect equines, viral diseases play an important role from a health and economic point of view, especially influenza, viral arteritis, herpes infections and vesicular stomatitis. In the Brazilian literature, there is little or no account of the occurrence of infectious diseases in donkeys. Given the importance of donkeys in different activities and the lack of information on infections that may occur in these animals, the aim of this study was to determine the frequency of anti-equine herpesvirus (EHV), anti-equine arteritis virus (EAV), anti-vesicular stomatitis, and anti-equine influenza (H3N8) antibodies in the serum of 85 donkeys bred in some regions of the state of São Paulo. We found the following antibody frequencies: 50.6\% (43/85) antibodies against influenza virus subtype H3N8, 47\% (40/85) anti-EHV, and 20\% (17/85) anti-EAV. The donkeys were not seropositive for vesicular stomatitis. The results suggested that the agents EHV, EAV, and equine influenza subtype H3N8 circulate among donkeys in some regions of the state of São Paulo, Brazil, reinforcing the importance of establishing a routine diagnosis and epidemiological study of this species.
\end{abstract}

Keywords: Donkeys. Equids. Serology. Infectious diseases. Brazil.

\section{Resumo}

Dentre as doenças que acometem os equídeos, as enfermidades virais assumem um papel importante do ponto de vista sanitário e econômico, especialmente a influenza, arterite viral, as infecções herpéticas e a estomatite vesicular. Na literatura nacional, existe pouco ou nenhum relato sobre a ocorrência de enfermidades infecciosas nos asininos. Tendo em vista a importância dos asininos para diferentes atividades e a falta de informações sobre as doenças que acometem esses animais, este trabalho teve como objetivo estudar a frequência de anticorpos anti-EHV, antivírus da arterite equina, anti-estomatite vesicular e anti-influenza equina (H3N8) em 85 soros de jumentos criados no estado de São Paulo. Estimou-se que 50,6\% apresentavam anticorpos contra o subtipo H3N8 do vírus da influenza; 47\% (40/85) apresentavam anticorpos contra o EHV e $20 \%$ apresentavam anticorpos contra o vírus da arterite. Os jumentos não foram soro reagentes contra a estomatite vesicular. Os resultados obtidos sugerem que os agentes EHV, vírus da arterite equina e influenza equina subtipo $\mathrm{H} 3 \mathrm{~N} 8$, circulam entre os jumentos do estado de São Paulo, caracterizando a importância do estabelecimento de uma rotina diagnóstica e estudos epidemiológicos na espécie.

Palavras-chave: Asininos. Equídeos. Sorologia. Enfermidades infecciosas. Brasil. 
Correspondence to:

Maria do Carmo Custódio de Souza Hunold Lara

Instituto Biológico

Av. Conselheiro Rodrigues Alves 1252 - Vila Mariana

CEP 04014-002, São Paulo, SP, Brazil

e-mail: lara@biologico.sp.gov.br

Received: 26/09/2016

Approved: 12/05/2017

\section{Introduction}

Herpesvirus infections in equids caused by equid alphaherpesvirus 1 (EHV-1) and 4 (EHV-4) can result in respiratory disease, epizootic abortion in mares, perinatal mortality in foals, and neurological disease (ATASEVEN et al., 2009; PUSTERLA; HUSSEY, 2014). It is known that EHV-1 is widely distributed among the horse population of Brazil and worldwide (MORI et al., 2014; PUSTERLA; HUSSEY, 2014). However, there are scarce serological studies on the presence of antibodies against herpesviruses in donkeys or mules in Brazil and abroad (ATASEVEN et al., 2009; CHENCHEV et al., 2011).

Equid alphaherpesvirus type 8 (EHV-8), former asinine herpesvirus type 3 (AHV-3), shows cross immunity with EHV-1 and EHV-4, where it is not distinguishable by the virus neutralization test and has been associated with respiratory disease in donkeys (BROWNING et al., 1988).

Equine arteritis virus (EAV) can cause respiratory and reproductive disease in equids (PAWESKA et al., 1995; BALASURIYA et al., 2014). As in horses, Paweska et al. (1995) demonstrated that virus transmission from an infected animal to a susceptible donkey occurs through the respiratory route. Furthermore, donkeys infected with EAV can infect mares and donkeys during mating (PAWESKA et al., 1995), because they can become unapparent carriers of the virus, harboring the agent in the semen. Serological surveys have shown that the virus circulates in equine populations in various regions of Brazil and some countries around the world. However, serological studies of viral arteritis in populations of donkeys and mules are restricted to the international literature.

Influenza is considered one of the most important respiratory diseases caused by viruses in equine breeding because it is highly contagious. Currently, influenza virus subtype $\mathrm{H} 3 \mathrm{~N} 8$ is responsible for epizootic outbreaks of disease in equids in many countries worldwide, including Brazil (LANDOLT, 2014). However, there are few serological studies regarding only donkeys in the literature.
Vesicular stomatitis is a disease of great economic importance because of trade barriers and quarantines. The detection of antibodies in horses is common without manifestation of clinical signs. There are only two reports of serological surveys of antibodies to the Indiana type vesicular stomatitis virus in donkeys. Fletcher et al. (1985) observed that $40 \%$ of donkeys were seropositive for this agent, indicating that this disease was enzootic on Ossabaw Island, located in the state of Georgia, United States. Turnbull et al. (2002), in turn, observed using the virus neutralization test that only $1.61 \%$ of the animals in the United Arab Emirates had antibodies to the same agent.

The presence of these agents involves both the health of equines and human health, and draws attention to the importance of adopting health measures in order to minimize their spread. In a research on the Brazilian literature, we found little or no account of the occurrence of infectious diseases in donkeys. Such knowledge is typically extrapolated from diseases occurring in horses. Despite equine pathogens being similar, the manifestation of the disease may be different in donkeys. For example, susceptibility to certain diseases may be different in this species.

Given the importance of donkeys for different activities and the lack of information on diseases that affect these animals, the objective of this study was to evaluate the occurrence of antibodies to viral agents affecting the donkeys bred in some regions of the state of São Paulo, Brazil.

\section{Materials and Methods}

\section{Samples}

We studied 85 serum samples collected from 2009 to 2010 , from donkeys belonging to 5 properties located in the municipalities of Pirassununga, Barretos, Colina, and Araçatuba, in São Paulo, Brazil. These animals were healthy and had history of vaccination against rabies and equine encephalomyelitis.

The donkey herds belonging to the 5 properties located in the state of São Paulo were characterized by small population associated with other livestock animals in greater numbers. Female donkeys had continuous access to pasture, while stallions were house in stalls.

\section{Immunodiagnostics}

Virus neutralization (VN) was used to determine neutralizing antibodies against the viruses EAV, EHV 1), 
and vesicular stomatitis types COCV and VSAV. Sera were tested at 2-fold dilutions for EHV-1, EAV, COCV, and VSAV against 100-200 TCID50/25 $\mu \mathrm{L}$ of suspension of EHV-1, EAV, COCV, and VSAV. After incubation for 1 hour at $37^{\circ} \mathrm{C}, 150 \mu \mathrm{L}$ of a suspension of VERO cells were added to the tests for EHV-1, COCV, and VSAV, and of RK-13 for EAV, containing 300,000 cells/mL. The reading for the different $\mathrm{VN}$ assays was performed after 48-72 hours of incubation in a $5 \% \mathrm{CO} 2$ incubator at $37^{\circ} \mathrm{C}$, in order to determine neutralization of the cytopathic effect. The samples were tested in duplicate, and antibody titer was expressed as the reciprocal of the last dilution that inhibited the appearance of cytopathic effect in both duplicates. Sera were considered reactive at titers $\geq 2$ for EHV- 1 and EAV and $\geq 32$ for COCV and VSAV, according to World Organisation For Animal Health (2015) recommendations.

Antibodies against equine influenza virus were determined by the hemagglutination inhibition (HI) technique. Sera were tested against the antigens A/EQ1 (sample SP/56 - H7N7) and A/Eq2 (sample SP/1/85 $\mathrm{H} 3 \mathrm{~N} 8$ ) with 4 hemagglutinating units (HU) by adding $0.5 \%$ rooster RBCs. Samples showing titers equal to or greater than $20 \mathrm{HU}$ were considered positive.

\section{Results and Discussion}

Of the total samples collected, $20.0 \%$ (17/85) were seropositive for EAV. Out of the five properties analyzed, seropositive animals were found only in two properties (Pirassununga and Colina). The highest incidence of EAVseropositive donkeys (41.6\%) occurred in the property located in Pirassununga-SP. It should be noted that this property was the only one that showed a male seropositive donkey, evidence of the importance of males in the spread (through semen) and in the persistence of the viral agent in the equids population (PAWESKA et al., 1995).

Using the virus neutralization technique, the results of this study showed similar results to those obtained by Paweska et al. (1997) and a comparatively higher rate than that determined in populations of animals seropositive for EAV in Turkey (YILDIRIM et al., 2008), South Africa (PAWESKA; BARNARD, 1993; PAWESKA et al., 1997), and the United Arab Emirates (TURNBULL et al., 2002).

This study showed that the donkeys bred in some regions of the state of São Paulo, Brazil, are also exposed to EAV. It should be emphasized that these animals belong in a region that has a large transit of horses participating in agricultural fairs and equestrian competitions.

With regard to EHV, 47\% (40/85) of the samples were seropositive. In this region of sample collection, abortions and pregnancy losses do occur in mares and donkeys, which can be related to this infectious agent. Similarly to studies by Ataseven et al. (2009), we demonstrated here that donkeys may act as reservoirs of alpha herpesvirus (such as EHV-1 and EHV-8), which affect horses.

The presence of anti-EHV antibodies was observed at all properties studied except Barretos. There was also a higher percentage of female positivity [54.5\% (36/66)], indicating a possible role of the mares in the maintenance of the viral agent in the equine population, which is evident in the transmission of herpesvirus during primary infection in nursing foals (GILKERSON et al., 1999).

For equine influenza, $54.1 \%$ (46/85) of the animals were seropositive for subtype $\mathrm{H} 3 \mathrm{~N} 8$. The distribution of $\mathrm{HI}$ titers was $41.3 \%(19 / 46)$ with $20,34.8 \%$ (16/46) with $40,13.0 \%$ (6/46) with $80,8.7 \%$ (4/46) with 160 , and $2.2 \%$ (1/46) with 320 . The results suggest that this virus circulates amongst donkeys in some regions of the state of São Paulo, Brazil, highlighting the importance of establishing a diagnostic and epidemiological routine for equine influenza virus, alerting health authorities to the possibility of outbreaks in donkeys as well.

Several studies describe the involvement of insects as vectors and potential reservoirs of vesicular stomatitis virus, because it is a disease with ecological limitation and seasonal incidence. Although the regions studied harbor hematophagous insects, no animal was positive for serotypes COCV and VSAV.

On the one hand, the role of donkeys in state of São Paulo, Brazil, is relatively irrelevant in terms of both population size and the health management they receive in relation to other livestock species. On the other hand, positive serological results (EHV, EAV, and equine influenza subtype H3N8) in some regions of the state of São Paulo suggest that donkeys may be an active or potential reservoir of these diseases that may be transmissible to other domestic livestock. No correlation was observed between seropositive animals for EAV, EHV, and influenza virus.

The ubiquity of infectious and parasitic diseases could contribute to reducing production, to poor work performance, and to premature mortality in donkeys. This further suggests the potential of these diseases in causing welfare problems and economical losses. 


\section{Conclusion}

The results of this study suggested that the agents EAV, $\mathrm{EHV}$, and equine influenza subtype H3N8 circulate among donkeys in some regions of the state of São Paulo, Brazil, pointing out the importance of establishing a routine diagnosis and epidemiological study of this species.

Serological evidence reported in this paper indicates that donkeys are susceptible to natural infections of theses mentioned microorganisms and strongly suggest that donkeys may be an active or potential reservoir of these diseases that may be transmissible to other domestic livestock.

\section{Acknowledgment}

We thank Fundação de Amparo à Pesquisa do Estado de São Paulo (FAPESP) for the financial support (2008/52048-9).

\section{References}

ATASEVEN, V. S.; DAĞALP, S. B.; GÜZEL, M.; BASARAN, Z.; TAN, M. T.; GERAGHTY, B. Prevalence of equine herpesvirus-1 and equine herpesvirus- 4 infections in equidae species in Turkey as determined by ELISA and multiplex nested PCR. Research in Veterinary Science, v. 86, n. 2, p. 339-344, 2009. doi: 10.1016/j.rvsc.2008.06.001.

BALASURIYA, U. B. Equine viral arteritis. Veterinary Clinics of North America: Equine Practice, v. 30, n. 3, p. 543-560, 2014. doi: 10.1016/j.cveq.2014.08.011.

BROWNING, G. F.; FICORILLI, N.; STUDDERT M. J. Asinine herpesvirus genomes: comparison with those of the equine herpesviruses. Archives of Virology, v. 101, p. 183-190, 1988. doi: 10.1007/BF01310999.

CHENCHEV, I. V.; RUSENOVA, N.; SANDEV, N. Seroepidemiological studies of donkeys' blood for detection of some virus infections on ungulates. Trakia Journal of Sciences, v. 9, n. 2, p 82-86, 2011.

FLETCHER, W. O.; STALLKNECHT, D. E.; JENNEY, E. W. Serologic surveillance for vesicular stomatitis virus on Ossabaw Island, Georgia. Journal of Wildlife Diseases, v. 21 , n. 2 , p. 100-104, 1985. doi: 10.7589/0090-355821.2.100.

GILKERSON, J. R.; WHALLEY, J. M.; DRUMMER, H. E.; STUDDERT, M. J.; LOVE, D. N. Epidemiology of EHV-1 and EHV-4 in the mare and foal populations on a Hunter Valley stud farm: are mares the source of EHV-1 for unweaned foals. Veterinary Microbiology, v. 68 , n. $1-2$, p. $27-34$, 1999. doi: 10.1016/S03781135(99)00058-9.
LANDOLT, G. A. Equine influenza virus. Veterinary Clinics of North America: Equine Practice, v. 30, n. 3, p. 507-522, 2014. doi: 10.1016/j.cveq.2014.08.003.

MORI, E.; MORI, C. M. C.; MAIORKA, P. C. Herpesvírus equino tipo 1: revisão de literatura. Revista do Conselho Federal de Medicina Veterinária, v. 61, p. 65-72, 2014.

PAWESKA, J. T.; BARNARD, B. J. Serological evidence of equine arteritis virus in donkeys in South Africa. Onderstepoort Journal of Veterinary Research, v. 60, n. 2, p. 155-158, 1993.

PAWESKA, J. T.; BINNS, M. M.; WOODS, P.S.; CHIRNSIDE, E. D. A survey for antibodies to equine arteritis virus in donkeys, mules and zebra using virus neutralisation (VN) and enzyme linked immunosorbent assay (ELISA). Equine Veterinary Journal, v. 29, n. 1, p. 40-43, 1997. doi: 10.1111/j.2042-3306.1997.tb01634.x.

PAWESKA, J. T.; VOLKMANN, D. H.; BARNARD, B. J.; CHIRNSIDE, E. D. Sexual and in-contact transmission of asinine strain of equine arteritis virus among donkeys. Journal of Clinical Microbiology, v. 33, n. 12, p. 3296-3299, 1995.

PUSTERLA, N.; HUSSEY, G. S. Equine herpesvirus 1 Myeloencephalopathy. Veterinary Clinics North America: Equine Practice, v. 30, n. 3, p. 489-450, 2014. doi: 10.1016/j.cveq.2014.08.006.

TURNBULL, A.; WERNERY, U.; WERNERY, R.; ANANDH, J. P.; KINNE, J. Survey of six infectious diseases of feral donkeys in the United Arab Emirates. Equine Veterinary Education, v. 14, n. 1, p. 33-38, 2002. doi: 10.1111/j.2042-3292.2002.tb00135.x. 
WORLD ORGANISATION FOR ANIMAL HEALTH (OIE). Terrestrial animal health code. 2015. Available from: <https://goo.gl/bcKXEq/>. Viewed: 18 Aug. 2016.
YILDIRIM, Y.; KIRMIZIGUL, A. H.; TAN, M. T.; GOKCE, E.; IRMAK, K. Seroprevalence of equine viral arteritis in donkeys in Kars District, Turkey. Journal of Animal and Veterinary Advance, v. 7, n. 9, p. 1110-1112, 2008. 